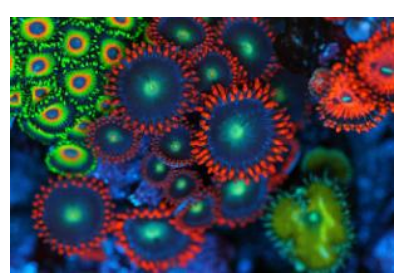

Zoanthus spp.

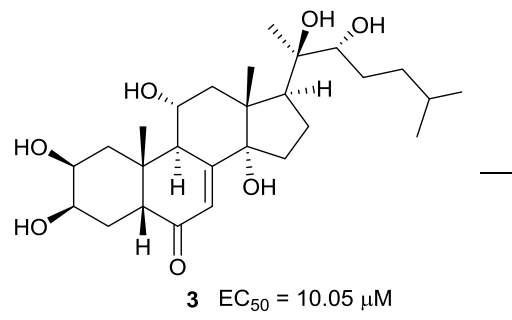

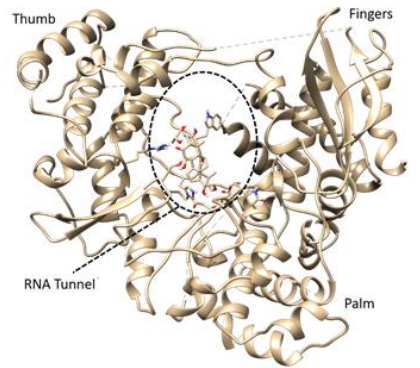




\section{Ecdysones from Zoanthus spp. with inhibitory activity against dengue virus 2}

Yuan-Bin Cheng, ${ }^{\mathrm{a}, \mathrm{b}, \dagger}$ Jin-Ching Lee, ${ }^{\mathrm{a}, \mathrm{c}, \dagger} \mathrm{I}-\mathrm{Wen}$ Lo, ${ }^{\mathrm{a}}$ Shu-Rong Chen, ${ }^{\mathrm{a}}$ Hao-Chun Hu, ${ }^{\mathrm{a}}$

Yu-Hsuan $\mathrm{Wu},{ }^{\mathrm{d}, \mathrm{e}}$ Yang-Chang Wu, ${ }^{\mathrm{f}, \mathrm{g}, \mathrm{h}, *}$ and Fang-Rong Chang ${ }^{\mathrm{a}, \mathrm{i}, \mathrm{j}, *}$

${ }^{\mathrm{a}}$ Graduate Institute of Natural Products, College of Pharmacy, Kaohsiung Medical

University, Kaohsiung 807, Taiwan

${ }^{\mathrm{b}}$ Center for Infectious Disease and Cancer Research, Kaohsiung Medical University, Kaohsiung 807, Taiwan

${ }^{\mathrm{c}}$ Department of Biotechnology, College of Life Science, Kaohsiung Medical

University, Kaohsiung, Taiwan

${ }^{\mathrm{d}}$ Institute of Basic Medical Sciences, College of Medicine, National Cheng Kung

University, Tainan, Taiwan

${ }^{\mathrm{e}}$ Center of Infectious Disease and Signaling Research, College of Medicine, National

Cheng Kung University, Tainan, Taiwan

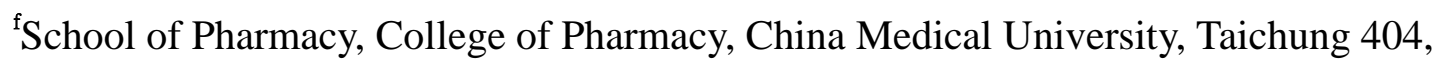

Taiwan

${ }^{g}$ Chinese Medicine Research and Development Center, China Medical University

Hospital Taichung 404, Taiwan

${ }^{\mathrm{h}}$ Center for Molecular Medicine, China Medical University Hospital, Taichung 404,

Taiwan

${ }^{\mathrm{i}}$ Department of Marine Biotechnology and Resources, National Sun Yat-sen

University, Kaohsiung 804, Taiwan 
${ }^{\mathrm{j}}$ Cancer Center, Kaohsiung Medical University Hospital, Kaohsiung 807, Taiwan

${ }^{\dagger}$ These authors contributed equally to this work.

*Corresponding authors. Tel: +886-4-22057153. Fax: +886-4-22060248. E-mail:

yachwu@mail.cmu.edu.tw (Y.-C. Wu); Tel: +886-7-3121-101-2162. Fax:

+886-7-3114-773. E-mail: aaronfrc@kmu.edu.tw (F.-R. Chang) 


\begin{abstract}
Bioassay-guided fractionation of an ethanolic extract of Zoanthus spp. collected in Taiwan has resulted in the isolation of one new ecdysone, zoanthone A (1), along with thirteen known compounds $(\mathbf{2}-\mathbf{1 4})$. The structures of these compounds were determined by spectroscopic methods, especially 2D NMR analyses. The in vitro antiviral activities of all isolated ecdysones (1-14) against dengue virus type 2 (DENV-2) were evaluated using DENV infectious system. New compound (1) exhibited potent antiviral activity $\left(\mathrm{EC}_{50}=19.61 \pm 2.46 \mu \mathrm{M}\right)$ with a selectivity index $\left(\mathrm{CC}_{50} / \mathrm{EC}_{50}\right)$ value of 36.7 . The structure-activity relationships of isolated ecdysones against DENV-2 were concluded. Molecular docking information of $\mathbf{3}$ and NS5 polymerase was performed either.
\end{abstract}

Keywords: Ecdysone; Zoanthus; Dengue virus type 2; Structure-activity relationships; Molecular docking 
Dengue virus (DENV) is an arbovirus transmitted by mosquito of the genus Aedes. Over 2.5 billion people living in the tropical and subtropical areas are susceptible to dengue virus. Infection of the four serotypes of DENV (DENV-1-4) gives rise to dengue fever, dengue hemorrhage fever, and dengue shock syndrome, which leads to a $20 \%$ death rate. Because this mosquito-borne disease has become a considerable global burden, there is an urgent need to develop its remedy. The DENV genome encodes three structural (C, prM and E) and seven non-structural (NS1, NS2A, NS2B, NS3, NS4A, NS4B and NS5) proteins. ${ }^{1}$ NS5 is the largest and the most conserved protein, comprising a $\mathrm{N}$-terminal methyltransferase domain for the viral RNA cap structure ${ }^{2,3}$ and a C-terminal RNA-dependent RNA polymerase (RdRp) domain which is essential for RNA replication and represents an attractive anti-DENV target. ${ }^{4,5}$ In our preliminary antiviral screening, the ethanol extract of Zoanthus spp. collected in the east coast of Taiwan showed inhibitory activity against DENV-2, the most infective and epidemic DENV in Asia. Therefore, this animal material was chosen for natural product study.

Sea anemone of the genus Zoanthus (family Zoanthidae) is widely distributed in the intertidal zones of subtropical or tropical region. This marine invertebrate are commonly cultured in aquarium because of its fascinating fluorescence. In previous natural product studies, fatty hydrocarbons, ${ }^{6}$ ecdysones, ${ }^{7}$ alkaloids,${ }^{8-15}$ and 
sphingolipids ${ }^{16}$ were purified as the major components of Zoanthus spp.. Ecdysone, steroidal hormone with a 14 $\alpha$-hydroxy-7-en-6-one chromophore, was frequently isolated from invertebrates and plants. Except for the moulting function toward arthropod, these type of steroids are regarded for their pesticidal, ${ }^{17}$ antidepressive, ${ }^{18}$ hepatoprotective, ${ }^{19}$ immunoprotective, ${ }^{20}$ and antiarrhythmic ${ }^{21}$ activities. Herein, the separation and structural elucidation of one new and thirteen known compounds (Figure 1) from the ethanolic extract of Zoanthus spp. are described. In addition, the in vitro anti-DENV-2 on NS5 polymerase activity and a docking study of DENV NS5 RdRp domain with the isolated ecdysteroids are performed.

The animal materials of Zoanthus spp. were collected in east Taiwan and extracted with $95 \%$ ethanol. After removing solvent, the residue was partitioned between $\mathrm{H}_{2} \mathrm{O}$ and EtOAc to yield an organic extract. A series of column chromatography of the EtOAc extract resulted in the isolation of one new ecdysone (1), together with thirteen known compounds, viticosterone $\mathrm{E}(\mathbf{2}),{ }^{22}$ ajugasterone $\mathrm{C}$ (3), ${ }^{23}$ 20-hydroxyecdysone (4), ${ }^{22} \alpha$-ecdysone (5), ${ }^{22}$ 24(28)-dehydromakisterone A $(\mathbf{6}),{ }^{24}$ 20-hydroxyecdysone 3 -acetate $(7),{ }^{25}$ ponasterone A (8),${ }^{26}$-deoxyecdysterone (9) ${ }^{22}$ pterosterone $(\mathbf{1 0}),{ }^{27}$ epi-inokosterone $(\mathbf{1 1}),{ }^{28}$ inokosterone $(\mathbf{1 2}),{ }^{28}$ turkesterone (13), ${ }^{22}$ and dihydropoststerone (14). ${ }^{29}$ The structures of all isolates were determined 
by their spectroscopic data.

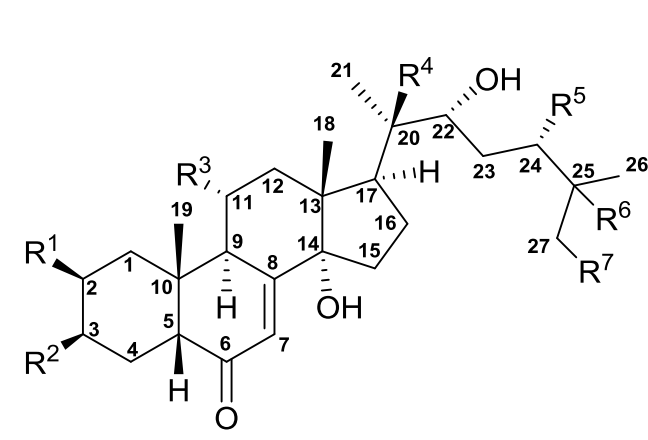

$1 \mathrm{R}^{1}=\mathrm{R}^{2}=\mathrm{R}^{3}=\mathrm{R}^{4}=\mathrm{OH}, \mathrm{R}^{5}=\mathrm{H}, \mathrm{R}^{6}=\mathrm{OAc}, \mathrm{R}^{7}=\mathrm{H}$

$2 \mathrm{R}^{1}=\mathrm{R}^{2}=\mathrm{OH}, \mathrm{R}^{3}=\mathrm{H}, \mathrm{R}^{4}=\mathrm{OH}, \mathrm{R}^{5}=\mathrm{H}, \mathrm{R}^{6}=\mathrm{OAc}, \mathrm{R}^{7}=\mathrm{H}$

$3 R^{1}=R^{2}=R^{3}=R^{4}=O H, R^{5}=R^{6}=R^{7}=H$

$4 \mathrm{R}^{1}=\mathrm{R}^{2}=\mathrm{OH}, \mathrm{R}^{3}=\mathrm{H}, \mathrm{R}^{4}=\mathrm{OH}, \mathrm{R}^{5}=\mathrm{H}, \mathrm{R}^{6}=\mathrm{OH}, \mathrm{R}^{7}=\mathrm{H}$

$5 \mathrm{R}^{1}=\mathrm{R}^{2}=\mathrm{OH}, \mathrm{R}^{3}=\mathrm{R}^{4}=\mathrm{R}^{5}=\mathrm{H}, \mathrm{R}^{6}=\mathrm{OH}, \mathrm{R}^{7}=\mathrm{H}$

$7 \mathrm{R}^{1}=\mathrm{OH}, \mathrm{R}^{2}=\mathrm{OAc}, \mathrm{R}^{3}=\mathrm{H}, \mathrm{R}^{4}=\mathrm{OH}, \mathrm{R}^{5}=\mathrm{H}, \mathrm{R}^{6}=\mathrm{OH}, \mathrm{R}^{7}=\mathrm{H}$

$8 \mathrm{R}^{1}=\mathrm{R}^{2}=\mathrm{OH}, \mathrm{R}^{3}=\mathrm{H}, \mathrm{R}^{4}=\mathrm{OH}, \mathrm{R}^{5}=\mathrm{R}^{6}=\mathrm{R}^{7}=\mathrm{H}$

$9 \mathrm{R}^{1}=\mathrm{H}, \mathrm{R}^{2}=\mathrm{OH}, \mathrm{R}^{3}=\mathrm{H}, \mathrm{R}^{4}=\mathrm{OH}, \mathrm{R}^{5}=\mathrm{H}, \mathrm{R}^{6}=\mathrm{OH}, \mathrm{R}^{7}=\mathrm{H}$

$10 \mathrm{R}^{1}=\mathrm{R}^{2}=\mathrm{OH}, \mathrm{R}^{3}=\mathrm{H}, \mathrm{R}^{4}=\mathrm{R}^{5}=\mathrm{OH}, \mathrm{R}^{6}=\mathrm{R}^{7}=\mathrm{H}$

$11,12 R^{1}=R^{2}=\mathrm{OH}, \mathrm{R}^{3}=\mathrm{H}, \mathrm{R}^{4}=\mathrm{OH}, \mathrm{R}^{5}=\mathrm{R}^{6}=\mathrm{H}, \mathrm{R}^{7}=\mathrm{OH}$

$13 \mathrm{R}^{1}=\mathrm{R}^{2}=\mathrm{R}^{3}=\mathrm{R}^{4}=\mathrm{OH}, \mathrm{R}^{5}=\mathrm{H}, \mathrm{R}^{6}=\mathrm{OH}, \mathrm{R}^{7}=\mathrm{H}$

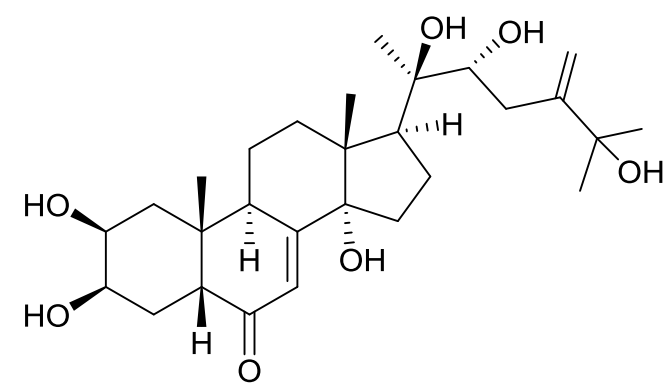

6

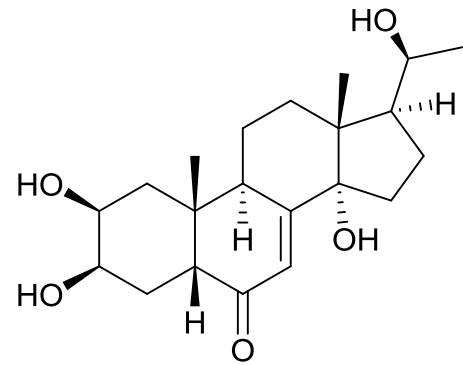

14

Figure 1. Structures of ecdysones 1-14 from Zoanthus spp..

Zoanthone A (1), $[\alpha]^{25} 47$ (c $\left.0.05, \mathrm{MeOH}\right)$, had a molecular formula of $\mathrm{C}_{29} \mathrm{H}_{46} \mathrm{O}_{9}$ and seven indices of hydrogen deficiency, as deduced from HRESIMS $(\mathrm{m} / \mathrm{z}$ $\left.561.3034[\mathrm{M}+\mathrm{Na}]^{+}\right)$and ${ }^{13} \mathrm{C}-\mathrm{NMR}$ spectra. The IR absorption bands of $\mathbf{1}$ revealed the presence of hydroxy $\left(3382 \mathrm{~cm}^{-1}\right)$, ketone $\left(1654 \mathrm{~cm}^{-1}\right)$, and C-O $\left(1026 \mathrm{~cm}^{-1}\right)$ functionalities. The Mass, IR and UV absorption (239 and $215 \mathrm{~nm}$ ) of 1 suggested that $\mathbf{1}$ possesses an ecdysone framework. The ${ }^{1} \mathrm{H}$ NMR data of $\mathbf{1}$ (Table 1) clearly indicated the presences of five tertiary methyls $(\delta 1.29,1.34,1.41,1.48$, and 1.63), one olefinic methine $(\delta 6.32)$, four oxymethines $(\delta 3.85,4.25,4.59$, and 4.61$)$, and one $O$-acetyl unit $(\delta 1.95)$. In the ${ }^{13} \mathrm{C}$ NMR (Table 1 ) and DEPT spectra of $\mathbf{1}$, twenty nine 
carbon signals were classified into one carbonyl ( $\delta$ 203.9), one ester carbonyl $(\delta$ 170.2), one olefinic methine ( $\delta$ 122.3), one olefinic quaternary carbon $(\delta 164.2)$, four oxygenated methines $(\delta 68.2,68.4,68.9$, and 77.4), three aliphatic methines $(\delta 42.8$, 50.0, and 52.5), two aliphatic quaternary carbons ( $\delta$ 39.5, and 48.1), three oxygen-bearing quaternary carbons $(\delta 76.8,82.3$, and 84.2), seven aliphatic methylenes $(\delta 21.5,26.9,31.9,32.9,39.3,39.9$, and 44.2), and six methyls $(\delta 18.9$, 20.2, 21.5, 24.9, 26.1, and 26.3). The above data accounted for three indices of hydrogen deficiency, which implied that $\mathbf{1}$ has a tetracyclic ring system. 
Table 1

\begin{tabular}{|c|c|c|c|}
\hline position & $\delta_{\mathrm{H}}$, mult $(J$ in $\mathrm{Hz})$ & $\delta_{\mathrm{C}}$, type & $\operatorname{HMBC}\left({ }^{1} \mathrm{H}^{-13} \mathrm{C}\right)$ \\
\hline \multirow[t]{2}{*}{1} & $2.01, \mathrm{t}(7.8)$ & $39.9, \mathrm{CH}_{2}$ & $2,3,5,9,10$ \\
\hline & $3.49, \mathrm{dd}(12.5,4.1)$ & & \\
\hline 2 & $4.59, \mathrm{~m}$ & $68.4, \mathrm{CH}$ & \\
\hline 3 & 4.25 , br s & $68.2, \mathrm{CH}$ & \\
\hline \multirow[t]{2}{*}{4} & $1.78, \mathrm{~m}$ & $32.9, \mathrm{CH}_{2}$ & \\
\hline & $2.06, \mathrm{dt}(9.1,2.1)$ & & \\
\hline 5 & $3.06, \mathrm{t}(8.5)$ & $52.5, \mathrm{CH}$ & \\
\hline 6 & & 203.9, C & \\
\hline 7 & $6.32, \mathrm{~d}(2.3)$ & $122.3, \mathrm{CH}$ & $5,9,14$ \\
\hline 8 & & 164.2, C & \\
\hline 9 & 3.90, dd $(8.6,2.4)$ & $42.8, \mathrm{CH}$ & 8,11 \\
\hline 10 & & $39.5, \mathrm{C}$ & \\
\hline 11 & $4.61, \mathrm{~m}$ & $68.9, \mathrm{CH}$ & \\
\hline \multirow[t]{2}{*}{12} & $2.72, \mathrm{dd}(12.4,6.3)$ & $44.2, \mathrm{CH}_{2}$ & $9,11,13,14,18$ \\
\hline & 3.07, d (14.2) & & $11,13,18$ \\
\hline 13 & & $48.1, \mathrm{C}$ & \\
\hline 14 & & $84.2, \mathrm{C}$ & \\
\hline \multirow[t]{2}{*}{15} & $1.83, \mathrm{~m}$ & $31.9, \mathrm{CH}_{2}$ & \\
\hline & $2.23, \mathrm{~m}$ & & \\
\hline \multirow[t]{2}{*}{16} & $2.18, \mathrm{~m}$ & 21.5, $\mathrm{CH}_{2}$ & \\
\hline & $2.47, \mathrm{~m}$ & & \\
\hline 17 & $3.09, \mathrm{t}(9.8)$ & $50.0, \mathrm{CH}$ & \\
\hline 18 & $1.29, \mathrm{~s}$ & $18.9, \mathrm{CH}_{3}$ & $12,13,14,17$ \\
\hline 19 & $1.34, \mathrm{~s}$ & $24.9, \mathrm{CH}_{3}$ & $1,5,9,10$ \\
\hline 20 & & 76.8, C & \\
\hline 21 & $1.63, \mathrm{~s}$ & $21.5, \mathrm{CH}_{3}$ & $17,20,22$ \\
\hline 22 & 3.85 , dd $(10.2,5.5)$ & $77.4, \mathrm{CH}$ & \\
\hline \multirow[t]{2}{*}{23} & $1.69, \mathrm{~m}$ & 26.9, $\mathrm{CH}_{2}$ & \\
\hline & $1.86, \mathrm{~m}$ & & \\
\hline \multirow[t]{2}{*}{24} & $2.14, \mathrm{~m}$ & $39.3, \mathrm{CH}_{2}$ & \\
\hline & $2.41, \mathrm{dd}(12.0,5.0)$ & & $25,26,27$ \\
\hline 25 & & $82.3, \mathrm{C}$ & \\
\hline 26 & $1.48, \mathrm{~s}$ & $26.3, \mathrm{CH}_{3}$ & $24,25,27$ \\
\hline 27 & $1.41, \mathrm{~s}$ & 26.1, $\mathrm{CH}_{3}$ & $24,25,26$ \\
\hline \multirow[t]{2}{*}{ OAc- 25} & $1.95, \mathrm{~s}$ & $170.2, \mathrm{C}$ & \\
\hline & & $20.2, \mathrm{CH}_{3}$ & \\
\hline
\end{tabular}

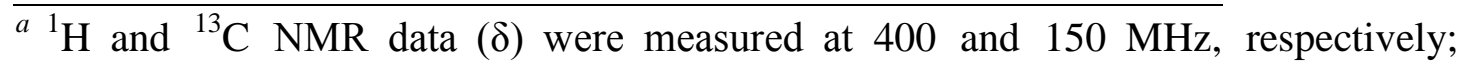
Chemical shifts are in ppm 
In the COSY spectrum, correlations of $\mathrm{H}_{2}-1(\delta 2.01$ and 3.49$) / \mathrm{H}-2(\delta 4.59) / \mathrm{H}-3(\delta$ $4.25) / \mathrm{H}_{2}-4(\delta 1.78$ and 2.06$) / \mathrm{H}-5(\delta 3.06), \mathrm{H}-9(\delta 3.90) / \mathrm{H}-11(\delta 4.61) / \mathrm{H}_{2}-12(\delta 2.72$ and 3.07), and $\mathrm{H}_{2}-15(\delta 1.83$ and 2.23$) / \mathrm{H}_{2}-16(\delta 2.18$ and 2.47$) / \mathrm{H}-17(\delta 3.09)$ were observed. This three proton sequences were connected by the key HMBC correlations of Me-19 $(\delta 1.34) / \mathrm{C}-1(\delta 39.9), \mathrm{C}-5(\delta 52.5), \mathrm{C}-9(\delta 42.8), \mathrm{C}-10(\delta 39.5)$ and Me-18 $(\delta$ 1.29)/C-12 $(\delta 44.2), \mathrm{C}-13(\delta$ 48.1), C-14 ( $\delta$ 84.2), C-17 ( $\delta$ 50.0). In addition, HMBC correlations of $\mathrm{H}_{2}-4 / \mathrm{C}-6(\delta$ 203.9), H-9/C-8 $(\delta$ 164.2), and H-7 $(\delta$ 6.32)/C-5, C-9, C-14 were used to establish the 7-en-6-one tetracyclic ring system of 1 (Figure 2). The HMBC correlation of $\mathrm{H}_{3}-21(\delta 1.63) / \mathrm{C}-17, \mathrm{C}-20(\delta 76.8), \mathrm{C}-22(\delta 77.4), \mathrm{Me}-26$ $(\delta$ 1.48)/C-24 ( $\delta$ 39.3), C-25 ( $\delta$ 82.3), C-27 ( $\delta$ 26.1), together with the COSY correlations of $\mathrm{H}-22(\delta \quad 3.85) / \mathrm{H}_{2}-23(\delta \quad 1.69$ and 1.86$) / \mathrm{H}_{2}-24(\delta 2.14$ and 2.41$)$ indicated the presence of side chain C-20 to C-27 and the connection between $\mathrm{C}-17$ and $\mathrm{C}-20$. The $O$-acetyl group was assigned at $\mathrm{C}-25$ by virtue of the similar C-25 chemical shift of $\mathbf{1}$ and $2 .{ }^{17}$ On the basis of those definitive 2D NMR analyses, the planar structure of $\mathbf{1}$ was established.

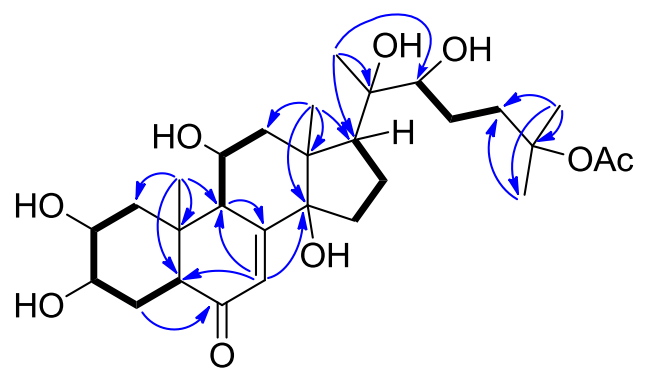

Figure 2. COSY (bold bond) and selected HMBC (arrow) correlations of $\mathbf{1}$. 
The stereochemistry of $\mathbf{1}$ was determined by its NOESY correlations (Figure 3) and by comparing its proton chemical shift with congeners. The NOESY correlations of $\mathrm{H}_{3}-19 / \mathrm{H}-5$ suggested that the A-B ring fusion of $\mathbf{1}$ should be cis. The hydroxy groups attached at C-2 and C-3 was both assigned on the $\beta$-face according to the NOESY correlations between $\mathrm{H}-3$ and H-2. The NOESY cross-peaks of $\mathrm{H}-19 / \mathrm{H}-11 / \mathrm{Me}-18$ revealed that these protons are on the $\beta$-face. In addition, the presence of NOESY correlations of $\mathrm{H}-17 / \mathrm{Me}-21$ and $\mathrm{H}-2 / \mathrm{H}-9$ proved the $\alpha$-orientation of these protons. On the basis of the similar proton chemical shift of $\mathbf{1}$ and cyasterone (structure was determined by X-ray single crystallographic analysis), ${ }^{30}$ the configurations of $\mathrm{C}-20$ and $\mathrm{C}-22$ were both determined to be $R$. Therefore, structure of $\mathbf{1}$ was determined and a trivial name zoanthone A was given.

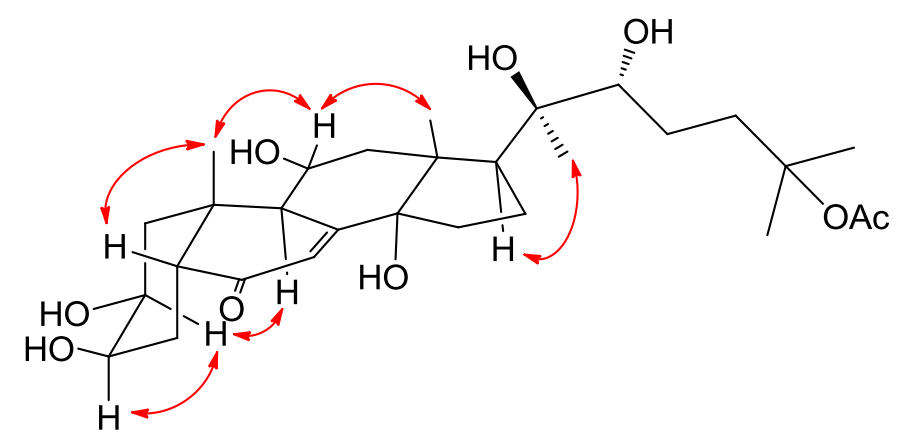

Figure 3. Key NOESY (left right arrow) correlations of $\mathbf{1 .}$

All isolated ecdysones were evaluated for their antiviral and cytotoxic activities. In the antiviral assay against dengue virus 2 by infectious system, compounds $\mathbf{1}$ and $\mathbf{3}$ were seen to be the most active substances with the $\mathrm{EC}_{50}$ value of $19.61 \pm 2.46 \mu \mathrm{M}$ and $10.05 \pm 2.37 \mu \mathrm{M}$, respectively. The other ecdysones demonstrated moderate to 
weak activities of DENV-2 inhibition. In a half maximal cytotoxicity test against Huh-7 cells, all tested compound showed no activity $\left(\mathrm{CC}_{50}>700 \mu \mathrm{M}\right)$. In addition, the most active compound $\mathbf{3}$ were also tested for its $\mathrm{EC}_{50}$ value against DENV-1 $(15.70 \pm 2.36 \mu \mathrm{M})$, DENV-3 $(9.48 \pm 0.24 \mu \mathrm{M})$, and DENV-4 $(12.15 \pm 1.22 \mu \mathrm{M})$. These results suggested $\mathbf{3}$ is active for all dengue virus serotypes.

According to our anti-DENV-2 results (Table 2), the following structure-activity relationships can be observed and illustrated in Figure 4:

(1) In comparison of compounds $\mathbf{4}$ and $\mathbf{9}$, the absence of a hydroxy group at C-2 is considerably decreases the $\mathrm{EC}_{50}$ value.

(2) Activity of compound $\mathbf{7}$, when compared to that of $\mathbf{4}$, shows that $O$-acetyl group at C-3 can decrease activity.

(3) The $\mathrm{EC}_{50}$ values of compounds $\mathbf{1}$ and $\mathbf{3}$ are less than that of $\mathbf{2}$, which suggest the presence of an $\alpha$-hydroxy group at C-11 can increase the anti-DENV activity.

(4) The close $\mathrm{EC}_{50}$ values of compounds $\mathbf{4}$ and $\mathbf{5}$ imply the presence of a hydroxy group at C-20 may not influence the activity.

(5) Compound $\mathbf{1 4}$ has no activity, so we can deduce that missing the side chain of C-23 to C-27 can markedly decrease activity.

(6) Presence of a hydroxy group at C-27 can strongly decrease anti-DENV-2 activity, as seen from compounds $\mathbf{1 2}$ is inactive and compound $\mathbf{1 1}$ has weak activity. 
Table 2

Anti-DENV-2 Activity of isolated compounds

\begin{tabular}{|c|c|c|c|}
\hline Compound & $\mathbf{E C}_{\mathbf{5 0}}(\boldsymbol{\mu} \mathbf{M})^{a}$ & $\mathbf{C C}_{50}(\boldsymbol{\mu} \mathbf{M})^{b}$ & $\mathbf{S I}^{c}$ \\
\hline 1 & $19.61 \pm 2.46$ & $>700$ & $>36.7$ \\
\hline 2 & $39.76 \pm 2.14$ & $>700$ & $>17.6$ \\
\hline 3 & $10.05 \pm 2.37$ & $>700$ & $>69.7$ \\
\hline 4 & $53.55 \pm 2.46$ & $>700$ & $>13.1$ \\
\hline 5 & $54.28 \pm 3.19$ & $>700$ & $>12.9$ \\
\hline 6 & $>100$ & $>700$ & - \\
\hline 7 & $87.34 \pm 4.54$ & $>700$ & $>8.0$ \\
\hline 8 & $>100$ & $>700$ & - \\
\hline 9 & $>100$ & $>700$ & - \\
\hline 10 & $\mathrm{NT}^{d}$ & NT & - \\
\hline 11 & $79.37 \pm 1.18$ & $>700$ & $>8.8$ \\
\hline 12 & $>100$ & $>700$ & - \\
\hline 13 & $38.15 \pm 2.40$ & $>700$ & $>18.3$ \\
\hline 14 & $>100$ & $>700$ & - \\
\hline $2 \mathrm{CMC}^{e}$ & $11.20 \pm 0.3$ & $94.75 \pm 4.15$ & $>8.5$ \\
\hline
\end{tabular}

${ }^{a}$ Half maximal effective concentraction. ${ }^{b}$ Half maximal cytotoxicity concentraction. $\quad{ }^{c}$ Selectivity index, $\quad \mathrm{CC}_{50} / \mathrm{EC}_{50} .{ }^{D}$ Not tested. ${ }^{e} 2$ '-C-methylcytidine, positive control. 


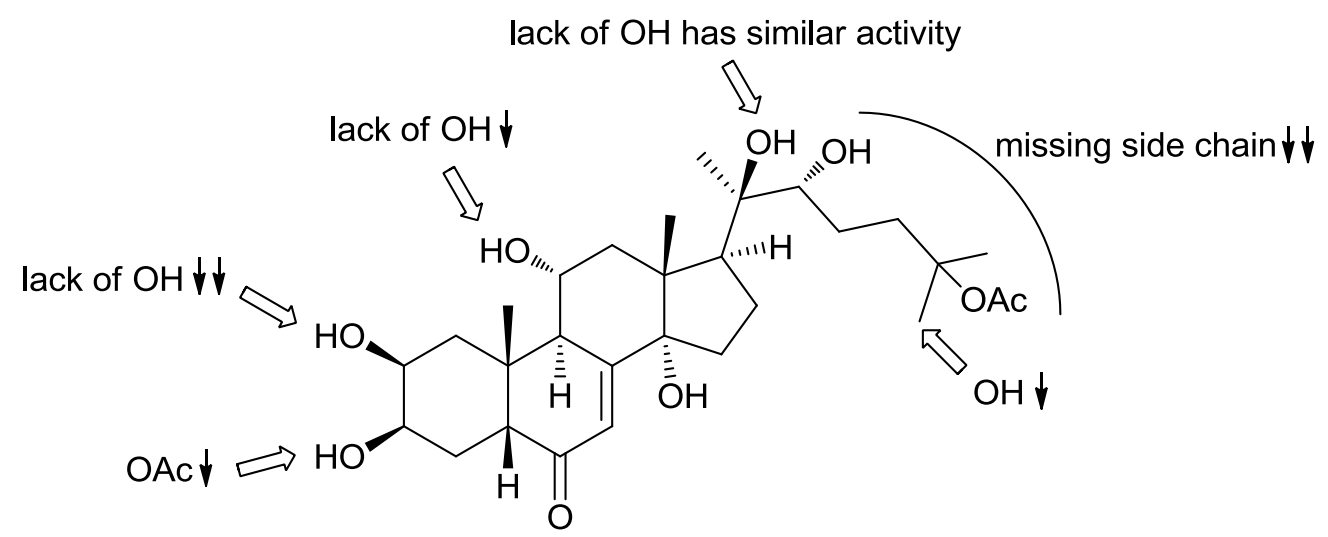

Figure 4. Structure-activity relationship studies for the effect of ecdysteroids against

DENV-2.The structural modifications leading to $\mathrm{EC}_{50}$ value changes is indicated by arrows $(\downarrow)$. The most active compound $\mathbf{3}$ was used for the SAR description.

In order to further understand the correlations of dengue virus polymerase and the active ecdysones, a computational protein-ligand binding simulation was carried out. A resemble conformation was observed in different DENV and West Nile virus RdRps, ${ }^{31}$ containing fingers, palm, and thumb subdomains in right handed topology. Therefore, X-ray crystallographic of RdRp (PDB code 2J7U) of DENV NS5 $5^{32,33}$ was adopted in our binding study. In silico docking calculations of NS5 RdRp with ajugasterone $\mathrm{C}(\mathbf{3})$ were illustrated in Figure 5, suggesting active compounds arrest DENV RNA replication by blocking the viral polymerase channel. Which findings corresponds to a current report, a synthetic non-nucleoside compound acts as an RdRp inhibitor by binding to an allosteric pocket in DENV RNA template tunnel. ${ }^{34}$ 

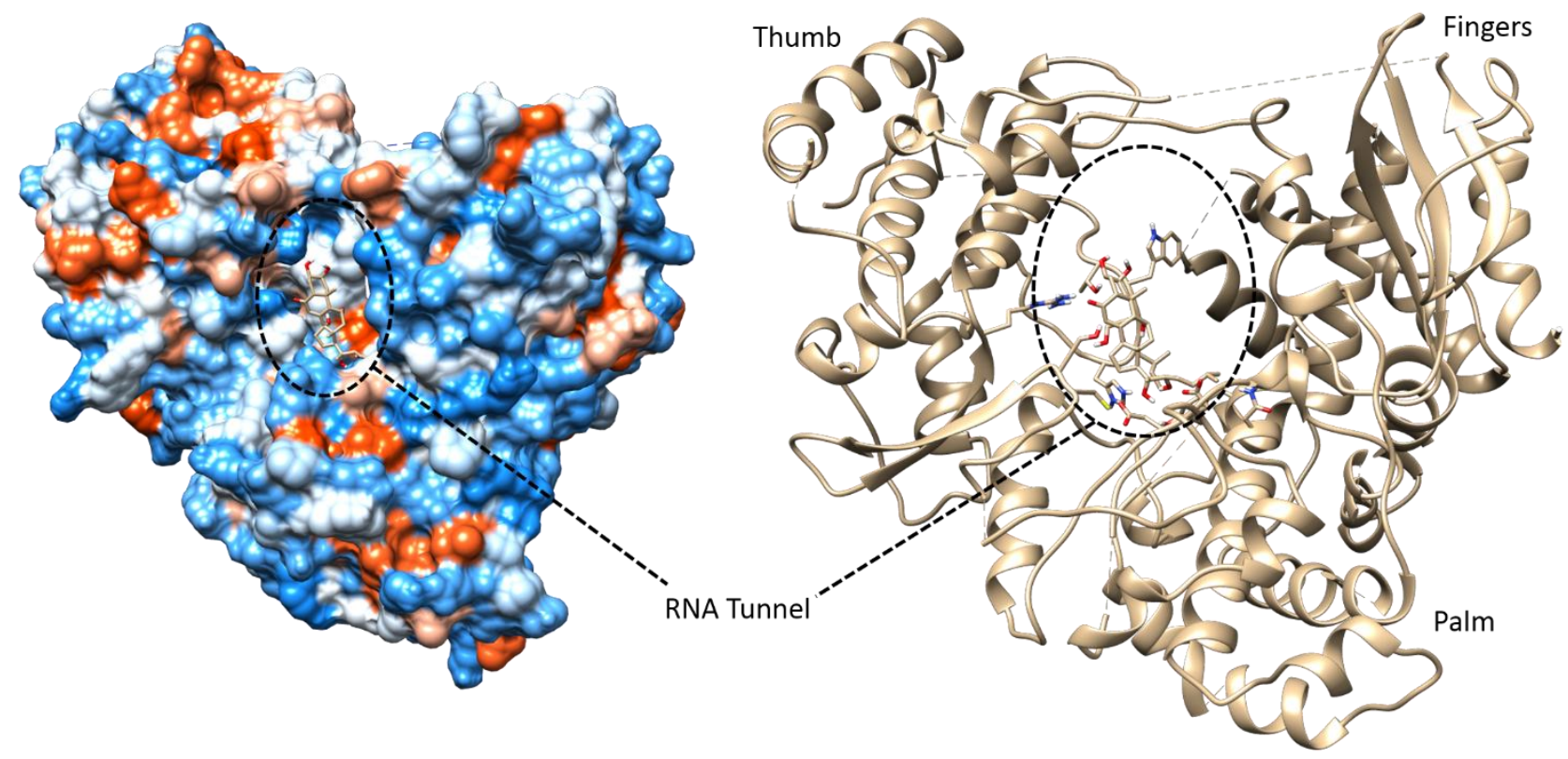

Figure 5. 3D model of overall complex of ecdysone-DENV RdRp entry represented in hydrophobicity surface (left) and ribbons (right). Compound $\mathbf{3}$ was chosen for illustration.

In the docking results (Figure S7) for ajugasterone C (3), three hydrogen bonds between $\mathrm{C}-6=\mathrm{O}$ and charged $\mathrm{NH}$ residue of $\mathrm{Arg} 729, \mathrm{OH}-2$ and backbone $\mathrm{NH}$ of Trp795, as well as $\mathrm{OH}-20$ and $\mathrm{NH}$ at imidazole His798 were observed. It is noted that 3 changed its pose and had four $\mathrm{H}$-bonds of $\mathrm{C}-6=\mathrm{O} / \mathrm{Ser} 710, \mathrm{OH}-2$ and OH-3/Asp533, and OH-20/Ile797 while the grip box size was shrunk (data not shown). To compare Zoanthone A (1) with $\mathbf{3}$, compound $\mathbf{1}$ cross-linked to RdRp by the same hydrogen bonding and possessed an extra linking between OAc- 25 and $\mathrm{NH}_{2}$ of Asn609. According to the docking results of selected compounds (Table S1), carbonyl group at C-6 and hydroxyl at C-2 are not only characteristics in ecdysone skeleton but also essential for their bioactivities. Furthermore, molecular modeling studies of these 
protease-ligand complexes also ascertained the influence of hydroxy groups in ecdysone, revealing the following. Intermolecular hydrogen bond of $\mathrm{OH}-2$ and $\mathrm{OH}-3$ enhance the inhibition ability and are formed with backbone NH of Trp795 and OH of Thr794, respectively; and finally, $\mathrm{OH}-22$ at the side chain link to the carbonyl substituents of Asp663 and/or Asp664, giving the bioactivity benefit. The information corresponded to the above structure activity relationship analyses.

Phytoecdysone has the function of insect repellent and is regard as a biomarker in many primitive plants such as ferns and gymnosperms. Zoanthid, a primitive invertebrate adapting to the above water environment, was found to secrete a series of ecdysones in our natural product investigation. This finding confirmed the ecological function of secondary metabolite usually acts as chemical defense substance. Besides, in vitro anti-dengue virus type 2 activity of ecdysones was first discovered. By the assistance of SAR and molecular docking analyses, the plausible action mechanism between ecdysone and DENV-2 NS5 polymerase was successfully proposed. Our findings not only demonstrate the structural diversity of marine natural products, but especially provide further insight into ecdysteroid as an anti-dengue virus agent.

\section{Acknowledgments}

This work was supported by grants from ministry of science and technology of Taiwan (MOST103-2628-B-037-001-MY3 award to Y.-B C.; MOST 
103-2320-B-037-005-MY2 award to F.-R C.), national health research institutes (NHRI-EX103-10241BI), and in part from the grant from Chinese medicine research center, China medical university (the ministry of education, the Aim for the Top University Plan). This study is also supported partially by Kaohsiung medical university (Aim for the Top Universities Grant, grant No. KMU-TP104H03, and KMU-TP104E40), ministry of health and welfare of Taiwan (MOHW105-TDU-B-212-134005), and health and welfare surcharge of tobacco products.

The RCSB PDB (http://www.rcsb.org/pdb/home/home.do), an information portal to 112968 biological macromolecular structures, is funded by a grant (DBI-1338415) from the National Science Foundation, the National Institutes of Health, and the US Department of Energy. AutoDock 4 (http://autodock.scripps.edu/) is free and is available under the GNU General Public License. AutoDock is Copyright $($ 1989-2015 The Scripps Research Institute. UCSF Chimera (https://www.cgl.ucsf.edu/chimera/) is a highly extensible molecular modeling system. Chimera is developed by the Resource for Biocomputing, Visualization, and Informatics, funded by the National Institutes of Health (NIGMS P41-GM103311).

\section{Supplementary data}

Supplementary data associated with this article can be found, in the online version, at 
http://

\section{References and notes}

1. Davidson, A. D. Adv. Virus Res. 2009, 74, 41.

2. Egloff, M. P.; Benarroch, D.; Selisko, B.; Romette, J. L.; Canard, B. EMBO J. 2002, 21, 2757.

3. Ray, D.; Shah, A.; Tilgner, M.; Guo, Y.; Zhao, Y.; Dong, H.; Deas, T.S.; Zhou, Y.; Li, H.; Shi, P.Y. J. Virol. 2006, 80, 8362.

4. Ackermann, M.; Padmanabhan, R. J. Biol. Chem. 2001, 276, 39926.

5. Tan, B. H.; Fu, J.; Sugrue, R. J.; Yap, E. H.; Chan, Y. C.; Tan, Y. H. Virology 1996, $216,317$.

6. Babu, U. V.; Bhandari, S. P. S.; Garg, H. S. Indian J. Chem. B 1996, 35, 627.

7. Suksamrarn, A.; Jankam, A.; Tarnchompoo, B.; Putchakarn, S. J. Nat. Prod. 2002, 65, 1194.

8. Rao, C. B.; Amjaneyula, A. S. R.; Sarma, N. S.; Venkatateswarlu, Y.; Rosser, R. M.; Faulkner, D. J.; Chen, M. H. M.; Clardy, J. J. Am. Chem. Soc. 1984, 106, 7933.

9. Rao, C. B.; Amjaneyula, A. S. R.; Sarma, N. S.; Venkatateswarlu, Y.; Rosser, R. M.; Faulkner, D. J. J. Org. Chem. 1985, 50, 3757.

10. Fukuzawa, S.; Hayashi, Y.; Uemura, D.; Nagatsu, A.; Yamada, K.; Ijuin, Y. 
Heterocycl. Commun. 1995, 1, 207.

11. Daranas, A. H.; Fernandez, J. J.; Gavin, J. A.; Norte, M. Tetrahedron 1998, 54, 7891.

12. Daranas, A. H.; Fernandez, J. J.; Gavin, J. A.; Norte, M. Tetrahedron 1999, 55, 5539.

13. Cen-Pacheco, F.; Norte, M.; Fernandez, J. J.; Daranas, A. H. Org. Lett. 2014, 16, 2880 .

14. Cheng, Y. B.; Lan, C. C.; Liu, W. C.; Lai, W. C.; Tsai, Y. C.; Chiang, M. Y.; Wu, Y. C.; Chang, F. R. Tetrahedron Lett. 2014, 55, 5369.

15. Cen-Pacheco, F.; Martin, M. N.; Fernandez, J. J.; Daranas, A. H. Mar. Drugs 2014, 12,5188 .

16. Babu, U. V.; Bhandari, S. P. S.; Garg, H. S. J. Nat. Prod. 1997, 60, 1307.

17. Dhadialla, T. S.; Carlson, G. R.; Le, D. P. Annu. Rev. Entomol. 1998. 43, 545.

18. Bathori, M.; Pongracz, Z. Current Medicinal Chemistry, 2005, 12, 153.

19. Badal'yants K. L.; Nabiev A. N.; Khushbaktova Z. A.; Syrov, V. N. Dokl. Akad. Nauk Uzbek 1996, 10, 46.

20. Fomovska, G. N.; Berdyshev, A. G.; Kholodova, Y. D. Ukr. Biokhim. Zh. 1992, $64,56$.

21. Maimeskulova, L. A.; Maslov, L. N. Eksp. Klin. Farmakol. 2000, 63, 29. 
22. Mamadalieva, N. Z.; Zibareva, L. N.; Saatov, Z. Chem. Nat. Compd. 2002, 38, 268.

23. Guerriero, A.; Pietra, R. Comp. Biochem. Physiol. 1985, 80B, 277.

24. Zhu, N.; Kikuzaki, H.; Vastano, B. C.; Nakatani, N.; Karwe, M. V.; Rosen, R. T.; Ho, C. T. J. Agric. Food Chem. 2001, 49, 2576.

25. Suksamrarn, A.; Pattanaprateep, P. Tetrahedron, 1995, 51, 10633.

26. Tanaka, N.; Murekami, T.; Saiki, Y.; Chen, C. M.; Gomez, L. D. Chem. Pharm. Bull. 1981, 29, 3455.

27. Suksamrarn, A.; Yingyongnarongkul, B.; Charoensuk, S. Tetrahedron 1999, 55, 255.

28. Suksamrarna, A.; Promrangsana, N.; Jintasirikul, A. Phytochemistry 2000, 53, 921.

29. Irault, J. P.; Bathori, M.; Varga, E.; Szendrei, K.; Lafont, R. J. Nat. Prod. 1990, $53,279$.

30. Okuzumi, K.; Hara, N.; Uekusa, H.; Fujimoto, Y. Org. Biomol. Chem. 2005, 3, 1227.

31. Malet, H.; Egloff, M. P.; Selisko, B.; Butcher, R. E.; Wright, P. J.; Roberts, M.; Gruez, A.; Sulzenbacher, G.; Vonrhein, C.; Bricogne, G.; Mackenzie, J. M.; Khromykh, A. A.; Davidson, A. D.; Canard, B. J. Biol. Chem. 2007, 282, 10678. 
32. Yap, T. L.; Xu, T.; Chen, Y. L.; Malet, H.; Egloff, M. P.; Canard, B.; Vasudevan, S. G.; Lescar, J. J. Virol. 2007, 81, 4753.

33. Iglesias, N. G.; Filomatori, C. V.; Gamarnik, A. V. J. Virol. 2011, 85, 5745.

34. Niyomrattanakit, P.; Chen, Y. L.; Dong, H. P.; Yin, Z.; Qing, M.; Glickman, J. F.; Lin, K.; Mueller, D.; Voshol, H.; Lim, J. Y. H.; Nilar, S.; Keller, T. H.; Shi, P. Y. J. Virol. 2010, 84, 5678.

35. Lee, J. C.; Tseng, C. K.; Wu, Y. H.; Kaushik-Basu N.; Lin, C. K.; Chen, W. C.; Wu, H. N. Antiviral Res. 2015, 116, 1. 